\title{
Diet, self-management and metabolic control in Norwegian teenagers with type I diabetes
}

\author{
Nina Lorentsen' and Ingunn Bergstad ${ }^{2}$ \\ 'Helgelandssykehuset avd. Mosjøen, Mosjøen, Norway; ${ }^{2}$ Department of Nutrition and Dietetics, Aker University \\ Hospital, Oslo, Norway
}

Abstract

Background: Nutritional recommendations for people with diabetes have changed in the past 15-20 years, and few studies have focused on dietary management in adolescents with diabetes.

Objective: To study dietary intake, metabolic control and self-management among teenagers with type 1 (insulin-dependent) diabetes.

Design: A quantitative food frequency questionnaire and an additional questionnaire were used to study dietary intake, self-management and lifestyle factors, including smoking habits, among 49 teenagers aged 1319 years. Height, weight, glycosylated haemoglobin $\left(\mathrm{HbA}_{1 \mathrm{c}}\right)$, total cholesterol and HDL cholesterol were also measured.

Results: The participants had five meals daily. Frequent meals seemed to have an impact on glycaemic control. The boys' energy intake from fat was very high, and there was a high intake of saturated fat. Fibre intake was lower than recommended, while sugar consumption was satisfactory. The girls had lower intake of vitamin $\mathrm{D}$, calcium, magnesium and iron than recommended. Median $\mathrm{HbA}_{1 \mathrm{c}}$ was $8.6 \%$. Those who measured their blood glucose less than daily had poorer glucose control than those who measured it at least three times a day. The prevalence of overweight was high.

Conclusions: Few teenagers had satisfactory metabolic control. Frequent meals and regular glucose monitoring seemed to have an impact on blood glucose control. The results also indicate that fat quality and intake of micronutrients should be emphasized.

Keywords: diet; diabetes; HbAlc; IDDM; self-management.

Received: 24 Jun. 2004; Revised: 15 Nov. 2004; Accepted: 22 Dec. 2004

\section{Introduction}

Few studies have focused on dietary management in adolescents with diabetes. In Norway the dietary intake among young people with diabetes has not been investigated since 1982 (1). In this connection dietary advice has changed since the early 1980s, from almost total elimination of sugar and sugarcontaining foods and beverages, to favour the intake of more carbohydrate and less protein and fat (2-5), and with a focus on the type of fat consumed (5). People with diabetes are today recommended to consume a diet similar to that of the general population, with extra focus on meal frequency (3). Having diabetes complicates everyday life. Physiological and psychological changes during puberty result in impaired metabolic control (6), and diabetes puts an extra strain on an already strenuous time of life. The purpose of this study was to investigate diet, lifestyle, metabolic control and self-management among teenagers with type 1 diabetes in Oslo. The study was conducted with some support from the Norwegian Diabetes Foundation.

\section{Subjects and methods}

\section{Subjects and study design}

All patients with diabetes aged 13-19 years attending the clinic Norsk Diabetikersenter (Norwegian Centre for Diabetics) or the children's clinic at Aker hospital, both in Oslo, Norway, were invited to take part in the study. In total, 50 of the 112 invited teenagers responded. Exclusion criteria were pregnancy and diabetes diagnosed $<1$ year before 
inclusion. Only patients diagnosed at least 1 year before inclusion were invited, and one of the girls was pregnant. Thus, the final sample consisted of 49 teenagers ( 21 boys and 28 girls), which gives a participation rate of $44 \%$.

Data collection was carried out during AprilJune 1998. The participants attended Norsk Diabetikersenter for anthropometric measurements and to give blood samples, and were interviewed by the dietitian (NL) for the collection of nutritional and diabetes-related data.

\section{Calculation of body mass index and basal metabolic rate and prevalence of misreporting}

Weight and height were measured by standardized methods. Body mass index (BMI) was computed as weight $(\mathrm{kg})$ divided by height $\left(\mathrm{m}^{2}\right)$. No standard definition of excess weight or obesity in adolescents is defined in Norway. Karlberg et al. (7) have developed a set of BMI reference curves for Swedish children, based on a longitudinal study of 3650 children followed from birth to 18 years of age. Mean \pm 2 standard deviations (SD) constitutes the normal area of age-specific BMI, and children with a BMI outside this range should, according to Karlberg et al., receive attention. Adolescents with a BMI over 2 SD above mean BMI for age can be defined as overweight (e.g. BMI $>27.5 \mathrm{~kg} \mathrm{~m}^{-2}$ for 18-year-old girls). BMI values for each of the participants were put into these reference curves.

Estimates of basal metabolic rate (BMR) were calculated from standard formulae based on height, weight, gender and age (8). A comparison of the energy intake with the estimate of BMR can be used to assess the number of respondents in a dietary survey who may underreport their food intake (9). Reported energy intake is divided by estimated BMR, to create a "BMR factor". For children and adolescents aged 6-18 years, cut-off values are set to 1.39-2.24 for boys and 1.35-2.10 for girls (10). A median BMR factor below these values suggests underreporting of energy intake at a group level, while BMR factors above the upper values indicate overestimation. A cut-off value for individual underreporters of 1.14 is suggested (9). With this cut-off value it is, according to Goldberg et al. (9), very unlikely that people with a naturally low energy intake would be identified as underreporters.

\section{Biochemical measurements}

Non-fasting blood samples were taken to assess metabolic control. Glycosylated haemoglobin $\left(\mathrm{HbA}_{1 \mathrm{c}}\right)$ was analysed from capillary blood tests using Norsk Diabetikersenter's standardized method, DCA $2000^{\circledR}$ Analyzer (Bayer), an immunological quick test specific for $\mathrm{HbA}_{1 \mathrm{c}}$ (reference area 3-6\%). Serum total cholesterol and highdensity lipoprotein (HDL)-cholesterol were analysed from venous samples, by means of BMcholesterol-PAP and HDL-C Plus (Boehringer Mannheim).

\section{Collection of dietary and nutritional data}

A quantitative food frequency questionnaire designed and validated at Section for Dietary Research, University of Oslo (11), was used to study the main part of the adolescents' dietary pattern and nutritional intake. The questionnaire is adapted to adolescents as it was designed in connection with a nationwide dietary survey of 13- and 18-year-old teenagers $(12,13)$, and has been evaluated against 7 day weighed records (11). The 12 page questionnaire has questions about 190 food items grouped together according to the typical Norwegian meal pattern. The questionnaire is phrased to give the "usual" intake during the past year. The questionnaire was completed through interviews conducted by the dietitian (NL), and data from the questionnaire were read optically at the Section for Dietary Research, University of Oslo.

Meal pattern was investigated through the following questions: How often do you usually eat the following meals (breakfast, lunch, dinner and supper) during the week ( $0-7$ times)? and How often during the day do you usually eat or drink something (e.g. fruit, bread, sweets, soft drinks) in addition to the main meals (seldom, once, twice, 3 times, 4-5 times)? Snacks in connection with hypoglycaemic episodes were not specified.

Daily intake of foods and nutrients was computed using a food database and software system developed at the Section for Dietary Research. Cod liver oil, vitamin and mineral preparations are not included in the calculations, because only the frequency, not the amount, was asked for.

An additional questionnaire was designed and used to assess diabetes-related parameters. The questionnaire contained eight main questions for assessing consumption of artificial sweeteners, physical activity, smoking habits, frequency of 
hypoglycaemic symptoms, blood glucose selfmonitoring, insulin doses and additional conditions. This paper reviews only results regarding smoking habits, hypoglycaemic symptoms and blood glucose self-monitoring, and these parameters were investigated through the following questions: Do you smoke (No; Yes, sometimes; Yes, every day)? How often do you experience hypoglycaemic symptoms like sweating, shivering, hunger, aggressiveness, etc. $(<1,1-3,4-6$ times per week; $1-2,>3$ times per day)? and How often do you measure your blood glucose level $(<1,1-2,3-4,5$ times or more per day; If more than 5 times daily, how many times per day; If less than daily, how many times per week)? The additional questionnaire was completed through interviews conducted by the dietitian, who also manually read the data from the questionnaire.

\section{Statistical methods}

All data were analysed using the program SPSS (Statistical Package for the Social Sciences), version 8.0 (SPSS-PC, Chicago, USA, 1997). Since most of the data were skewed, and there were relatively few participants, non-parametric statistical methods were chosen. Descriptive data that were computed were sample medians, 25 th and 75 th percentiles, and frequency analyses. Differences between medians were tested with the Mann-Whitney $U$-test, and relationships between dietary components and other factors were investigated using KruskallWallis $H$-test, chi-square tests and Spearman's correlation coefficients $\left(r_{\mathrm{s}}\right) . p$-Values of $\leq 0.05$ were considered statistically significant.

\section{Results}

\section{Age, duration of diabetes and anthropometric measurements}

The median age was 16 years, varying between 13 and 19 years, and the median duration of the diagnosis was 8 years. Table 1 shows anthropometric measurements of the study participants. One boy $(5 \%)$ and six girls $(21 \%)$ were classified as overweight, i.e. had a BMI at least 2 SD above mean BMI for age.

\section{Meal pattern}

The median number of meals was 5.0 per day (3.6 main meals and 2 light meals or snacks), varying between 3.3 and 8.2 daily meals. Most of the participants reported having all "usual" main meals at least five times a week. Dinner was the main meal most often eaten, as $90 \%$ had dinner five times a week or more. Breakfast, lunch and supper were eaten at least five times a week by 82,80 and $71 \%$ of the participants, respectively. There was a negative correlation between $\mathrm{HbA}_{1 \mathrm{c}}$ and the weekly number of breakfast meals $\left(r_{\mathrm{s}}=-0.33, p<0.03\right)$. There also was a negative correlation between $\mathrm{HbA}_{1 \mathrm{c}}$ and the number of main meals per day $\left(r_{\mathrm{s}}=-0.29\right.$, $p<0.05)$. There was no significant correlation between $\mathrm{HbA}_{1 \mathrm{c}}$ and total meals.

\section{Food consumption}

Table 2 presents median daily consumption of foods and food groups related to the total amount eaten (g per $10 \mathrm{MJ}$ ). The food composition of the diet was somewhat different in girls and boys. The girls reported consuming more vegetables, fruit and berries, yoghurt and syrup (e.g. fruit syrup, both sugar-free and with sugar added) per $10 \mathrm{MJ}$ than the boys, whereas the boys consumed more edible fat. Meat consumption was considerably higher than the intake of fish, in both genders.

\section{Energy and basal metabolic rate}

The reported daily energy intake is presented in Table 3. The median daily energy intake in boys aged 13-14 years was $11.7 \mathrm{MJ}$, and in boys aged 15-19 years 12.3 MJ. The girls in the same age groups had a median intake of 8.4 and $7.5 \mathrm{MJ}$, respectively. To evaluate the prevalence of misreporting of energy intake the BMR factor (reported energy intake divided by calculated BMR) was calculated. The median BMR factor in boys was 1.68 , and in girls $1.22(p<0.05)$, which suggests a tendency towards underreporting rather than overestimation of energy intake, especially among the girls. Nineteen per cent of the boys and $43 \%$ of the girls had a BMR factor below 1.14.

\section{Nutrient intake}

The macronutrient composition and intake of micronutrients are listed in Tables 4 and 5, and differed somewhat between the genders. Median protein intake was slightly higher than recommended in both groups. Boys had a significantly higher percentage of energy from fat, whereas girls had higher intake of dietary fibre and energy from carbohydrate. All of the boys and $61 \%$ of the girls exceeded the national recommendation of a 
Table I. Weight, height, body mass index (BMI) and standard deviations (SD) from mean BMI for age ${ }^{a}$ of the study participants

\begin{tabular}{|c|c|c|c|c|}
\hline & \multicolumn{2}{|c|}{$\operatorname{Median}\left(P_{25}, P_{75}\right)^{b}$} & \multirow[b]{2}{*}{$p$-Value ${ }^{c}$} & \multirow[b]{2}{*}{ Reference area } \\
\hline & $\begin{array}{l}\text { Boys } \\
(n=2 \mathrm{I})\end{array}$ & $\begin{array}{l}\text { Girls } \\
(n=28)\end{array}$ & & \\
\hline Weight (kg) & $67.0(53.9,77.5)$ & $62.1(56.4,76.2)$ & & \\
\hline Height (m) & $1.76(1.71,1.80)$ & $1.66(1.61,1.72)$ & & \\
\hline BMI $\left(\mathrm{kg} \mathrm{m}^{-2}\right)$ & $21.8(19.6,24.4)$ & $24.3(21.3,26.7)$ & $0.01 *$ & \\
\hline$S D$ from mean & $+0.5(0.0,1.0)$ & $+1.25(0.5,2.0)$ & $0.02^{*}$ & Mean \pm 2 SD \\
\hline BMI for age & & & & \\
\hline
\end{tabular}

${ }^{\text {a }}$ Based on Swedish reference curves for BMI for age (7).

${ }^{b} P_{25}$ : 25th percentile; $P_{75}$ : 75th percentile.

c Mann-Whitney $U$-test.

${ }^{d}$ Proposed by Karlberg et al. (7).

*Significant at $p<0.05$.

maximum 30\% energy intake from fat. Saturated fat intake was high and polyunsaturated fat intake low compared with the recommendations. Energy percentage from carbohydrate was lower than recommended, and in both genders sugar consumption was satisfactory according to the recommendations. Two boys (10\%) and four girls (14\%) had more than the recommended $10 \%$ of energy intake from sugar.
In both genders the median daily intake of dietary fibre was lower than recommended. Only $25 \%$ of the girls and $10 \%$ of the boys followed the recommendation of a minimum of $3 \mathrm{~g}$ of fibre per MJ. Among boys, fibre intake from snacks (potato chips, nuts, etc.) was higher than from vegetables. Twelve boys (57\%) and eight girls (29\%) reported consuming alcohol. Among the consumers, median

Table 2. Food intake

\begin{tabular}{|c|c|c|c|}
\hline & \multicolumn{3}{|c|}{ Food intake $\left(\mathrm{g} 10 \mathrm{MJ}^{-1}\right)$, median $\left(P_{25}, P_{75}\right)^{a}$} \\
\hline & Boys $(n=2 \mathrm{I})$ & Girls $(n=28)$ & $p$-Value \\
\hline Bread & $205(174,267)$ & $219(160,259)$ & 0.95 \\
\hline Cakes & $29(|3,9|)$ & $30(15,63)$ & 0.98 \\
\hline Potatoes (fresh) & $82(42,119)$ & $73(23,122)$ & 0.44 \\
\hline Vegetables & $67(39,88)$ & I44 (7I, 20I) & $<0.01 *$ \\
\hline Fruits, berries and products & $116(64,200)$ & $220(188,347)$ & $<0.01 *$ \\
\hline Fresh fruit & $4 \mid(25, \mid 16)$ & $148(1 \mid 8,212)$ & $<0.01 *$ \\
\hline Meat and products & $150(111,177)$ & $128(83,159)$ & 0.26 \\
\hline Fish and products, shellfish & $45(30,56)$ & $25(15,54)$ & 0.19 \\
\hline Eggs & $13(8,17)$ & $8(4,17)$ & 0.35 \\
\hline Milk & $332(178,561)$ & $179(69,547)$ & 0.59 \\
\hline Yoghurt & $8(1,39)$ & $37(8,80)$ & $0.03 *$ \\
\hline Cheese & $31(12,67)$ & $37(18,66)$ & 0.23 \\
\hline Edible fat & $51(36,59)$ & $33(23,52)$ & $<0.01 *$ \\
\hline Sweets, chocolate & $16(8,33)$ & $26(10,46)$ & 0.23 \\
\hline Ice cream & $17(9,24)$ & $20(11,37)$ & 0.20 \\
\hline Chips, nuts, etc. & $17(10,31)$ & $16(6,25)$ & 0.43 \\
\hline Mineral water & $304(169,411)$ & $217(168,383)$ & 0.60 \\
\hline Syrup/juice & $74(14,129)$ & $192(43,365)$ & $0.01 *$ \\
\hline
\end{tabular}

${ }^{\text {a }} \mathrm{P}_{25}$ : 25th percentile; $\mathrm{P}_{75}$ : 75th percentile.

b Mann-Whitney $U$-test

c Most of the consumption consists of mineral water without sugar.

*Significant at $p<0.05$. 
Table 3. Energy intake

\begin{tabular}{lll}
\hline & & $\begin{array}{l}\text { Energy intake }(\mathrm{MJ} \text { day } \\
\text { Median }\left(\mathrm{P}_{25}, \mathrm{P}_{75}\right)^{\mathrm{a}}\end{array}$ \\
\hline Boys & $13-14$ years $(n=7)$ & $11.7(5.8,13.3)$ \\
$(n=21)$ & $15-19$ years $(n=14)$ & $12.3(10.1,14.1)$ \\
& Total & $12.1(9.5,13.4)$ \\
Girls & $13-14$ years $(n=5)$ & $8.4(7.0,11.3)$ \\
$(n=28)$ & $15-19$ years $(n=23)$ & $7.5(6.7,8.4)$ \\
& Total & $7.8(6.7,9.2)$ \\
$P$-Value $^{\text {b }}$ & & $<0.0 I^{*}$ \\
\hline
\end{tabular}

${ }^{\text {a }} P_{25}$ : 25th percentile; $P_{75}$ : 75th percentile

b Mann-Whitney $U$-test boys versus girls (Total).

*Significant at $p<0.05$

energy intake from alcohol was $1.5 \%$ and $2.2 \%$ in boys and girls, respectively.

The boys had a satisfactory intake of all micronutrients, according to the recommendations. Among girls the intake of vitamin $\mathrm{C}$ and $\mathrm{B}$ vitamins was in accordance with the recommendations, whereas the intake of vitamin D barely exceeded $50 \%$ of the recommended $5 \mu \mathrm{g}$ day $^{-1}$. The girls' median intake of calcium, magnesium and iron was also lower than recommended. The boys had on average a significantly higher total intake of vitamins and minerals than the girls. When the nutrient density of the diet (amount of nutrient per MJ) is compared, the girls appeared to have significantly higher intake of vitamin $\mathrm{C}$, iron and magnesium than the boys, whereas the boys' vitamin D intake exceeded the girls' intake.
Use of dietary supplements was more frequent among girls $(64 \%)$ than among boys (33\%).

\section{Smoking habits}

About $71 \%$ of the boys and $75 \%$ of the girls were non-smokers, while $10 \%$ boys and $14 \%$ girls were daily smokers. There was a significant age difference between the smokers and non-smokers (17 vs 15 years, $p<0.05)$. $\mathrm{HbA}_{1 \mathrm{c}}$ was higher among smokers than among non-smokers (9.3 vs $8.2 \%, p=0.02$ ).

\section{Metabolic control}

Median $\mathrm{HbA}_{1 \mathrm{c}}$ was $8.6 \%$ in boys and $8.5 \%$ in girls ( $8.6 \%$ in total). About $19 \%$ of the boys and $25 \%$ of the girls had an $\mathrm{HbA}_{1 \mathrm{c}}$ value below $7.5 \%$, as recommended by the Norwegian College of General Practitioners (5). Figure 1 shows the distribution of $\mathrm{HbA}_{1 \mathrm{c}}$ values among both genders. The median serum cholesterol was $4.7 \mathrm{mmol}^{-1}$. Five per cent of the boys and $11 \%$ of the girls had serum cholesterol values higher than the official aim of treatment $\left(<6.5 \mathrm{mmol}^{-1}\right)$ (5). HDL-cholesterol was $1.48 \mathrm{mmol}^{-1}$, with all participants above the recommended $0.9 \mathrm{mmol}^{-1}$ (5). The median ratio between total and HDL-cholesterol was 3.2. None of the boys, but $11 \%$ of the girls, had a ratio exceeding the recommended ratio of 5 (5).

\section{Hypoglycaemic symptoms}

None of the participants reported having symptoms of hypoglycaemia more than three times a week. About $48 \%$ boys and $25 \%$ girls experienced hypo-

Table 4. Energy intake from protein, fat, carbohydrates and alcohol, and fibre intake. E\%: energy per cent, i.e. the portion of the total energy intake covered by the nutrient; SFA: saturated fatty acids; MUFA: monounsaturated fatty acids; PUFA: polyunsaturated fatty acids.

\begin{tabular}{|c|c|c|c|c|}
\hline & \multicolumn{2}{|c|}{ Median $\left(P_{25}, P_{75}\right)^{a}$} & \multirow[b]{2}{*}{$p$-Value ${ }^{\mathrm{b}}$} & \multirow[b]{2}{*}{ Recommended intake } \\
\hline & Boys $(n=2 \mathrm{I})$ & Girls $(n=28)$ & & \\
\hline Protein $(E \%)$ & $15.3(13.8,16.1)$ & $15.4(14.2,17.2)$ & 0.63 & $10-15$ \\
\hline Fat $(E \%)$ & $37.9(34.1,40.1)$ & $31.4(27.7,34.1)$ & $<0.001 *$ & $\leq 30$ \\
\hline SFA $(E \%)$ & $14.6(13.0,16.1)$ & $13.0(11.1,15.2)$ & $<0.03 *$ & $\leq 10^{\mathrm{d}}$ \\
\hline MUFA (E\%) & $13.7(12.0,14.4)$ & $10.9(9.4,11.9)$ & $<0.001 *$ & $10-15$ \\
\hline PUFA (E\%) & $6.9(5.2,7.4)$ & $4.8(4.1,5.5)$ & $<0.001 *$ & $5-10$ \\
\hline Carbohydrate (E\%) & $46.8(42.7,49.2)$ & $50.9(47.8,54.1)$ & $<0.001 *$ & $55-60$ \\
\hline Sugar $(E \%)$ & $6.3(4.4,8.6)$ & $5.7(3.2,8.1)$ & 0.57 & $\leq 10$ \\
\hline Alcohol $(E \%)$ & $0.1(0,1.7)$ & $0(0,0.2)$ & 0.09 & $<5^{\mathrm{e}}$ \\
\hline Fibre $(\mathrm{g})$ & $25(21,27)$ & $21(13,4 \mid)$ & & $25-30$ \\
\hline Fibre $\left(\mathrm{g} \mathrm{MJ}^{-1}\right)$ & $2.0(1.9,2.3)$ & $2.6(2.2,3.1)$ & $<0.01 *$ & 3 \\
\hline
\end{tabular}

${ }^{a} P_{25}$ : 25th percentile; $P_{75}: 75$ th percentile. ${ }^{b}$ Mann-Whitney $U$-test. ${ }^{c}$ National Nutrition Council (4). ${ }^{d}$ Includes trans monounsaturated fat. ${ }^{\text {e }}$ Total alcohol abstinence is recommended for children under 18 years of age. A limited alcohol consumption is recommended for adults, no more than $5 \%$ of total energy intake (4).

*Significant at $p<0.05$. 


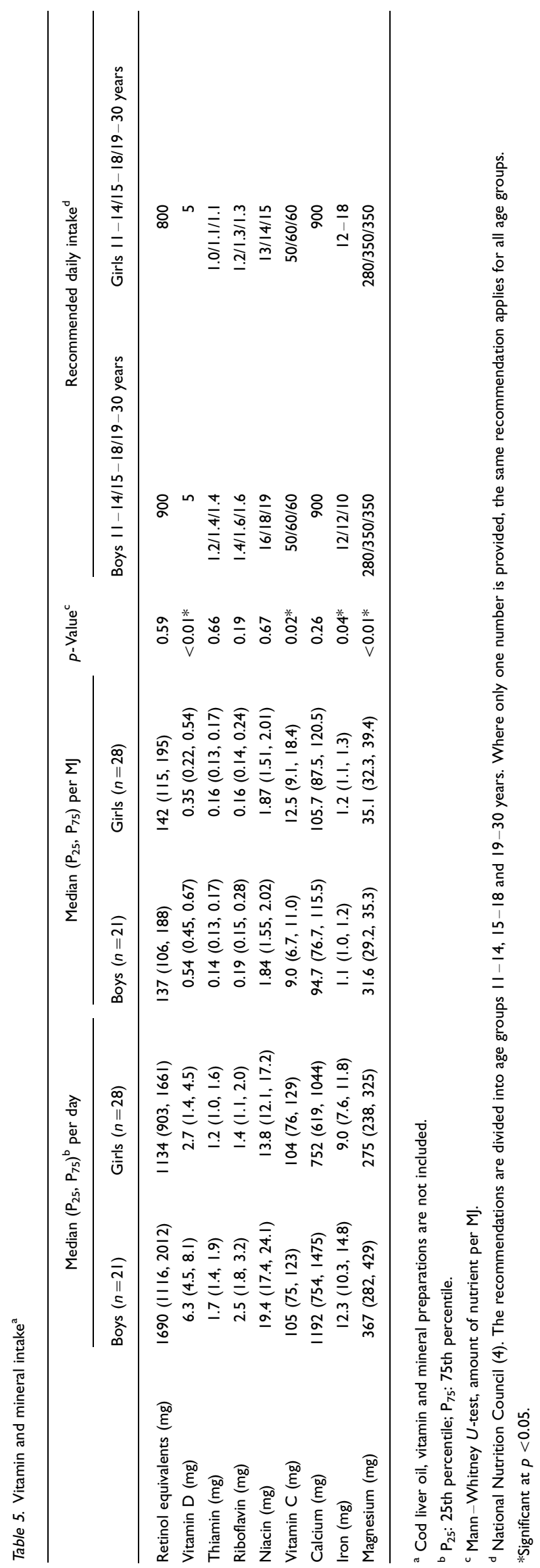

glycaemia less frequently than weekly. The girls tended to have hypoglycaemic symptoms more often than the boys $(p=0.10)$. $\mathrm{HbA}_{1 \mathrm{c}}$ among those who reported having hypoglycaemic symptoms less than weekly was $8.8 \%$, while the group reporting $1-$ 3 "lows" per week had a median $\mathrm{HbA}_{1 \mathrm{c}}$ of $8.4 \%$ $(p=0.21)$.

\section{Blood glucose self-monitoring}

Twenty-nine per cent of the participants measured their blood glucose less than daily, while 39\% measured at least three times per day, of whom $14 \%$ reported five measurements or more per day. Those who carried out three or more measurements per day had significantly lower $\mathrm{HbA}_{1 \mathrm{c}}$ than those who did not measure every day (7.6 vs $8.9 \%$, $p<0.01)$.

\section{Discussion}

The main purpose of this study was to investigate dietary intake in a group of teenagers in Oslo with type 1 diabetes. The results must be interpreted with caution, as the number of participants was relatively small and the prevalence of underreporting of energy intake seemed to be considerable. The low participation rate may be due to the fact that this was a group of diabetic patients who frequently participated in research projects, especially those who attended the Aker hospital, in which there was a special unit for diabetes research. Some of the dropouts may have been tired of participating in such studies. Moreover, data collection took place in connection with school examinations, which may have prevented some of the teenagers from taking part in the study. The authors are uncertain whether the group is representative of teenagers with type 1 diabetes in Norway, as important data from the non-participating group are lacking, e.g. regarding body composition and socioeconomic variables. Neither age (16 vs 17 years) nor $\mathrm{HbA}_{1 \mathrm{c}}$ (8.6 vs $8.9 \%$ ) differed significantly between the participants and the non-responders, respectively, but the group has to be considered as a sample of individuals who represent themselves. $\left(\mathrm{HbA}_{1 \mathrm{c}}\right.$ values for non-responders were collected from their patient journals. All blood samples had been analysed within 1 year, most of them within 2 months, before the study was carried out.)

The biochemical measurements were taken in the non-fasting state, to enable data to be collected after 


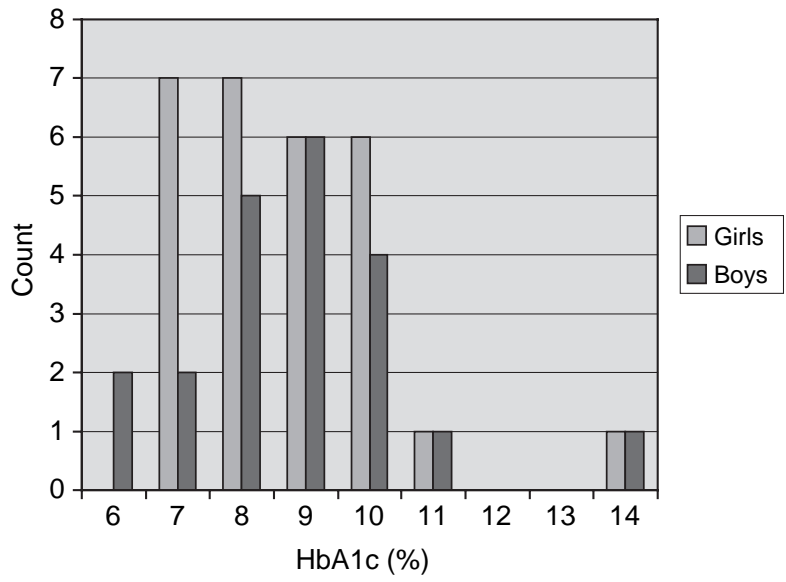

Fig. 1. Distribution of glycosylated haemoglobin $\left(\mathrm{HbA}_{1 \mathrm{c}}\right)$ among girls and boys $(n=49)$.

school, as the data collection took place during an examination period.

\section{Body mass index and prevalence of overweight}

The group had median BMI values higher than the mean BMI values in the reference curves presented by Karlberg et al. (7). This indicates that these adolescents with diabetes are heavier than teenagers in general, especially the girls, whose median BMI was 1.25 SD higher than the mean reference BMI for age. If the median BMI values from a Norwegian nationwide survey of 13- and 18 -year-old adolescents $(12,13)$ are plotted into the curves from Karlberg et al., the BMI values appear to be closer to the mean BMI for age (i.e. "normal" weight) compared with the present participants. As many as $21 \%$ of the girls in this study had a BMI of more than 2 SD above mean BMI for age, and hence were classified as overweight. These results are in agreement with observations in several other studies, where investigators have found that girls with diabetes tend to develop overweight in puberty, and that the prevalence of overweight is higher among young girls with diabetes than among non-diabetic girls of the same age (14-16).

\section{Meal pattern}

The participants seemed to follow the recommendations favouring frequent meals rather than few and large meals (5). Despite variation in the meal frequency, only a few participants had very few or extremely frequent meals. The number of meals in this study agrees with findings in other surveys of children and adolescents with diabetes $(1,17,18)$. Compared with healthy Norwegian teenagers (12, 13), the differences concerning meal pattern appear to be insignificant. In the 1982 study, children and adolescents with diabetes (1) seemed to have a more rigid meal pattern than found among the teenagers in the current study. This difference may come from the changes in insulin regimens, with increased room for day-to-day variations in meal pattern, and the fact that nutritional advice for people with diabetes has become more flexible.

The numbers of breakfast meals per week and main meals per day were both negatively correlated with $\mathrm{HbA}_{1 \mathrm{c}}$. Bjørgaas et al. (18) also found a negative correlation between the number of meals and $\mathrm{HbA}_{1 \mathrm{c}}$ among children with diabetes, and concluded that meal frequency was one of the most important parameters for metabolic control. It may be that frequent meals were a result of compensatory behaviour in connection with hypoglycaemic episodes, the frequency of which increases as $\mathrm{HbA}_{1 \mathrm{c}}$ is reduced (19). However, neither Bjørgaas nor the present group studied the frequency of meals taken in connection with hypoglycaemia, indicating that frequent, planned meals are still important in the treatment of diabetes.

\section{Food consumption}

Median daily consumption of foods and food groups was in general quite similar to Andersen and colleagues' findings among healthy Norwegian adolescents $(12,13)$. As an exception, the teenagers with diabetes, especially the girls, had a significantly higher consumption of vegetables. The total milk consumption was similar in both studies, but the intake of yoghurt was considerably lower among the present participants than among Andersen's teenagers. This may suggest that these are products people with diabetes use sparingly, as most yoghurt in Norway contains considerable amounts of added sugar. There was, however, no difference in the consumption of sweets and chocolate between the present group and the non-diabetic teenagers. The use of soft drinks was considerably higher in this survey than in Andersen's study. In this study the intake came almost exclusively from sugar-free drinks, whereas the other teenagers consumed insignificant amounts of light soft drinks. An explanation for the considerable consumption of mineral water can be that elevated blood glucose levels result in thirst and thereby enhanced fluid 
intake. In addition, sugar-free soft drinks have the advantage of tasting sweet without increasing blood glucose, and therefore can be an alternative to sugar-containing sweets.

In comparison with the 12-14-year-old Norwegian children with diabetes in Skåra's study (1), the teenagers in the present study had a higher intake of cakes. The girls also consumed significantly more sweets, chips and ice cream than the young girls in Skåra's survey. This was not surprising, as such foods were "forbidden" for people with diabetes at that time. In Skåra's study, the intake of sweet foods consisted almost exclusively of sugar-free products, which in the current study seemed to be consumed in very small amounts. The girls in this study seemed to consume almost $70 \%$ less edible fat than the girls in Skåra's survey, which can be explained partly by the great extent of underreporting, but also by the considerable focus in recent years on reducing fat intake.

\section{Energy and nutrient intake}

Energy intake in both genders was considerably lower than in the study by Andersen et al. $(12,13)$ among healthy Norwegian teenagers (15.0 and 15.8 MJ for boys aged 13 and 18 years, 10.9 and $9.9 \mathrm{MJ}$ for girls aged 13 and 18 years, respectively). Energy intakes in other surveys of people in comparable age groups with diabetes $(17,20,21$; energy intake between 10.1 and 11.5 MJ among boys, and 8.09.0 MJ among girls) are in closer agreement with the present results. However, Andersen et al. suspected in their paper that there was an overestimation of food intake, whereas the present teenagers, especially the girls, seemed to underestimate energy intake. In a recent Swedish study validating diet history against the doubly labelled water technique, Sjöberg et al. (22) found mean energy intakes of 13.5 MJ for boys and 8.3 MJ girls aged 15-16 years. The prevalence of underreporting in this survey was 11 and $41 \%$ among boys and girls, respectively, i.e. quite similar to the findings of this study. This indicates that differences in energy consumption between young people with diabetes and healthy adolescents may result from the distinct occurrence of misreporting, although there is little focus on this issue in the studies of diabetic adolescents mentioned above.

Recent research in the field of misreporting of food intake has provided increased knowledge about the prospects and pitfalls of using compar- isons between reported energy intake and estimated energy expenditure. Livingstone et al. (23) showed that there are considerable limitations using the "Goldberg cut-off" method (9), especially when applied to children. Their research, however, indicated that this method underestimated the prevalence of underreporters using diet history methods. This further increases the suspicion of considerable underreporting in the present group of adolescents.

The distribution of energy from energy-yielding nutrients was somewhat different than among healthy Norwegian teenagers $(12,13)$, with a higher energy percentage derived from protein, a considerably higher fat intake, especially among the boys, and a lower carbohydrate intake, probably because of a significantly lower sugar consumption. In comparison with other studies of children and adolescents with diabetes $(1,17,20,21)$, the present study showed a lower intake of energy from protein, a lower fat intake among the girls, and a slightly higher carbohydrate intake, including energy percentage from sugar. The Norwegian study from 1982 (1) showed a sugar consumption of only $1 \%$ of total energy intake, and the main sources of sugar were fish products, preserved vegetables, cakes, and "diabetic" sweets and desserts. It seems as though sugar consumption gradually has increased, but the current results indicate that young people with diabetes still use sugar sparingly.

The energy derived from fat was very high among the boys, who had a fat intake of $38 \%$ of total energy and without exception exceeded the recommended maximum intake. Intake of saturated compared with unsaturated fat was generally high, which is unfortunate considering the increased risk of cardiovascular disease seen in diabetes. The fact that the fat intake among the boys was considerably higher than among the girls may be explained by the different prevalence of underreporting. Price et al. (24) found a lower amount of energy derived from fat among underreporters than among adequate reporters. In a prospective study of children with diabetes, with a comprehensive treatment programme including considerable focus on dietary education (25), the mean energy percentage derived from fat was 31 . The children with $\mathrm{HbA}_{1 \mathrm{c}}$ values below $8.3 \% 5$ years after diagnosis had significantly lower fat intake $(30 E \%)$ than those with $\mathrm{HbA}_{1 \mathrm{c}}$ above $8.3 \%$. They also found a significant correlation between the energy percentage ingested as fat and $\mathrm{HbA}_{1 \mathrm{c}}$. These results indicate that the impor- 
tance of dietary fat must be emphasized even more in diabetes education, especially for those who exhibit poor metabolic control.

Fibre intake was lower than recommended, but higher than among healthy adolescents $(12,13)$, and similar to the levels of intake seen in other studies of young people with diabetes $(17,20)$. Only Virtanen et al. (21) have observed a fibre intake higher than the recommended $3 \mathrm{~g} \mathrm{MJ}^{-1}$. Among the boys in the present study, fibre intake from snacks (potato chips, nuts, etc.) was higher than from vegetables. This finding, and the very variable fibre intake among the girls, are thought-provoking results if they are representative of young people with diabetes.

Intake of micronutrients was generally low among the girls. This applied in particular for vitamin $\mathrm{D}$, of which the median consumption was only $54 \%$ of the recommended intake. This should be given attention, as only $14 \%$ of the girls regularly consumed supplements containing vitamin D. However, the degree of underreporting among the girls may explain the low consumption of micronutrients. Other studies of children and adolescents with diabetes have not revealed similar results, which may be related to a different prevalence of misreporting. Virtanen et al. (21) observed a micronutrient intake similar to the recommendations, and Samuelson et al. (17) found a higher nutrient density among people with diabetes than among controls. Agreement on the impact of micronutrient consumption in diabetes has not yet been established. Several authors have discussed different aspects of this issue (26-28). Supplementation with certain micronutrients could be favourable, although the evidence so far is too inconsistent to make official recommendations. However, it is certainly at least as important for people with diabetes as for the general population to have a diet with high nutrient density.

\section{Metabolic control}

Median $\mathrm{HbA}_{1 \mathrm{c}}$ was $8.6 \%$. This agrees with results from other studies of children and adolescents with diabetes $(17-19,29-32)$, where $\mathrm{HbA}_{1 \mathrm{c}}$ varied between $6.6 \%$ (29) and $10.1 \%$ (19; Secondary prevention group before intervention), but was mainly around $8 \%$. In the present study, only $22 \%$ had $\mathrm{HbA}_{1 \mathrm{c}}$ below $7.5 \%$, as recommended by the Norwegian College of General Practitioners (5). In a study by Bjørgaas et al. (18), only 18\% reached this aim of treatment. Rosilio et al. (30) and Mortensen and Hougaard (31) found that 33 and $34 \%$ of their children and adolescents had an $\mathrm{HbA}_{1 \mathrm{c}}$ under $8 \%$. In other words, it seems that relatively few children and adolescents manage to maintain satisfactory metabolic control.

Although it is well documented that tighter glycaemic control correlates with more episodes of hypoglycaemia $(19,25)$, the correlation between $\mathrm{HbA}_{1 \mathrm{c}}$ and the frequency of hypoglycaemic symptoms did not reach significance in this study. This may be related to the small sample of participants, as there seemed to be a tendency towards such a connection. However, the results regarding hypoglycaemia are somewhat doubtful, as the definition of the symptoms lacks precision.

\section{Glucose self-monitoring}

One-third of the participants measured their blood glucose less than daily. This group had significantly poorer metabolic control than those who carried out three or more measurements per day. Corresponding results have been shown in several studies $(19,29,30,33,34)$. This implies that blood glucose self-monitoring is important in maintaining satisfactory metabolic control.

\section{Conclusions}

Because of the significant prevalence of underreporting of energy, and the relatively small number of participants, the results of the present study must not be overinterpreted. With these reservations, it may be concluded that energy derived from fat was very high among the boys, and saturated fat intake was considerably higher than recommended. Because of the proven linkage between quality and quantity of dietary fat and cardiovascular disease, the importance of this aspect must be emphasized even more in educating patients with diabetes. Sugar consumption was quite low, indicating that young people with diabetes still use sugar sparingly. The results also imply that there should be a focus on nutrient density, as the consumption of several micronutrients was lower than recommended among the female participants.

There was a high prevalence of overweight, especially among the girls. Relatively few had satisfactory metabolic control. Frequent meals and frequent self-monitoring of blood glucose seemed to have an impact on metabolic control. 


\section{References}

1. Skåra BB. Tilpasning av kosten i diabetesbehandlingen. Hovedfagsoppgave i ernæringsfysiologi. Oslo: Johan Throne Holsts institutt for ernæringsforskning, Universitetet i Oslo; 1982.

2. Statens Ernæringsråd (National Nutrition Council). Diabeteskost. In: Statens Ernæringsråd. Retningslinjer for kostholdet i helseinstitusjoner. Oslo: Statens Ernæringsråd; 1985. p. 107-16.

3. Statens Ernæringsråd (National Nutrition Council). Hverdagskost, spesielle hensyn. In: Statens Ernæringsråd. Retningslinjer for kostholdet i helseinstitusjoner. Oslo: Universitetsforlaget; 1995. p. 65.

4. Statens Ernæringsråd (National Nutrition Council). Norske næringsstoffanbefalinger 1997. Oslo: Statens Ernæringsråd; 1997.

5. Claudi T, Midthjell K, Furuseth K, Hansen KF, Hestvold PI, Øgar P. NSAMs handlingsprogram for diabetes i allmennpraksis. Oslo: Norsk Selskap for Allmennmedisin (Norwegian College of General Practitioners); 1995.

6. Amiel SA, Sherwin RS, Simonson DC, Lauritano AA, Tamborlane WV. Impaired insulin action in puberty. A contributing factor to poor glycemic control in adolescents with diabetes. N Engl J Med 1986; 315: 215-9.

7. Karlberg J, Luo ZC, Albertsson-Wikland K. Body-mass index reference values (mean and SD) for Swedish children. Acta Paediatr 2001; 90: 1427-34.

8. FAO/WHO/UNU. Protein and energy requirements. WHO Technical Report Series 724. Geneva: World Health Organization; 1985.

9. Goldberg GR, Black AE, Jebb SA, Cole TJ, Murgatroyd PR, Coward WA, et al. Critical evaluation of energy intake data using fundamental principles of energy physiology: 1. Derivation of cut-off limits to identify under-recording. Eur J Clin Nutr 1991; 45: 569-81.

10. Torun B, Davies PSW, Livingstone MBE, Paolisso M, Sackett R, Spurr GB. Energy requirements and dietary energy recommendations for children and adolescents 1 to 18 years old. Eur J Clin Nutr 1996; 50(Suppl 1): S3781.

11. Andersen LF, Nes M, Lillegaard IT, Sandstad B, Bjørneboe G-EAa, Drevon CA. Evaluation of a quantitative food frequency questionnaire used in a group of Norwegian adolescents. Eur J Clin Nutr 1995; 49: $543-$ 54.

12. Andersen LF, Nes M, Bjørneboe G-EAa, Drevon CA. Food habits among 13-year-old Norwegian adolescents. Scand J Nutr/Näringsforskning 1997; 41: 150-4.

13. Andersen LF, Nes M, Sandstad B, Bjørneboe G-Eaa, Drevon CA. Dietary intake among Norwegian adolescents. Eur J Clin Nutr 1995; 49: 555-64.

14. Du Caju MVL, Rooman RP, De Beeck LO. Longitudinal data on growth and final height in diabetic children. Pediatr Res 1995; 38: 607-11.

15. Pietiläinen KH, Virtanen SM, Rissanen A, Rita H, Mäenpää J. Diet, obesity and metabolic control in girls with insulin dependent diabetes mellitus. Arch Dis Child 1995; 73: 398-402.
16. Domargård A, Särnblad S, Kroon M, Karlsson I, Skeppner G, Åman J. Increased prevalence of overweight in adolescent girls with type 1 diabetes mellitus. Acta Paediatr 1999; 88: 1223-8.

17. Samuelson G, Lenner RA, Carlgren G, Hardell LI, Johansson B, Jonsson G, Sandström B. Food and nutrient intakes in Swedish diabetic children. Eur $\mathbf{J}$ Clin Nutr 1989; 43: 801-3.

18. Bjørgaas M, Haugen S, Stene G, Hæreid PE, Vik T. Diabetes mellitus hos barn. Behandlingskontroll, sosiale forhold og egenomsorg. Tidsskr Nor Lægeforen 1994; 114: $1930-2$.

19. Diabetes Control and Complications Trial (DCCT) Research Group. Effect of intensive diabetes treatment on the development and progression of long-term complications in adolescents with insulin-dependent diabetes mellitus: Diabetes Control and Complications Trial. J Pediatr 1994; 125: 177-88.

20. Hackett AF, Court S, McCowen C, Parkin JM. Dietary survey of diabetics. Arch Dis Child 1986; 61: 67-71.

21. Virtanen SM, Räsänen L, Tumme R, Laitinen S, Mäenpää J, Virtanen M, Åkerblom HK. A follow-up study of the diet of Finnish diabetic adolescents. Acta Paediatr 1992; 81: 153-7.

22. Sjöberg A, Slinde F, Arvidsson D, Ellegård L, Gramatkovski E, Hallberg L, Hulthén L. Energy intake in Swedish adolescents: validation of diet history with doubly labelled water. Eur J Clin Nutr 2003; 57: $1643-$ 52.

23. Livingstone MBE, Robson PJ, Black AE, Coward WA, Wallace JMW, McKinley MC, et al. An evaluation of the sensitivity and specificity of energy expenditure measured by heart rate and the Goldberg cut-off for energy intake: basal metabolic rate for identifying misreporting of energy intake by adults and children: a retrospective analysis. Eur J Clin Nutr 2003; 57: 455-63.

24. Price GM, Paul AA, Cole TJ, Wadsworth MEJ. Characteristics of the low-energy reporters in a longitudinal national dietary survey. Br J Nutr 1997; 77: $833-51$.

25. Forsander G, Malmodin B, Eklund C, Persson B. Relationship between dietary intake in children with diabetes mellitus type 1 , their management at diagnosis, social factors, anthropometry and glycaemic control. Scand J Nutr 2003; 47: 75-84.

26. Elamin A, Tuvemo T. Magnesium and insulin-dependent diabetes mellitus. Diabetes Res Clin Pract 1990; 10: 203-9.

27. Seghieri G, Martinoli L, Miceli M, Ciuti M, D’Allessandri G, Gironi A, et al. Renal excretion of ascorbic acid in insulin-dependent diabetes mellitus. Int $\mathbf{J}$ Vit Nutr Res 1994; 64: 119-24.

28. Chugh SN, Kakkar R, Kalra S, Sharma A. An evaluation of oxidative stress in diabetes mellitus during uncontrolled and controlled state after vitamin E supplementation. J Assoc Physicians India 1999; 47: 380-3.

29. Dorchy H, Roggemans M-P, Willems D. Glycated hemoglobin and related factors in diabetic children 
and adolescents under 18 years of age: a Belgian experience Diabetes Care 1997; 20: 2-6.

30. Rosilio M, Cotton J-B, Wieliczko M-C, Gendrault B, Carel J-C, Couvaras O, et al. Factors associated with glycemic control. A cross-sectional nationwide study in 2579 French children with type 1 diabetes. Diabetes Care 1998; 21: 1146-53.

31. Mortensen HB, Hougaard P, Hvidøre Study Group on Childhood Diabetes. Comparison of metabolic control in a cross-sectional study of 2873 children and adolescents with IDDM from 18 countries. Diabetes Care 1997; 20: 714-20.

32. Schober E, Langergraber B, Rupprecht G, Rami B. Dietary intake of Austrian diabetic children 10 to 14 years of age. J Pediatr Gastroenterol Nutr 1999; 29: $144-7$.
33. Ziegler O, Kolopp M, Louis J, Musse JP, Patris A, Debry G, Drouin P. Self-monitoring of blood glucose and insulin dose alteration in type 1 diabetes mellitus. Diabetes Res Clin Pract 1993; 21: 51-9.

34. Nathan DM, McKitrick C, Larkin M, Schaffran R, Singer DE. Glycemic control in diabetes mellitus: have changes in therapy made a difference? Am J Med 1996; 100: $157-63$.

\section{Nina Lorentsen}

Klinisk ernæringsfysiolog

Falkvn. 5 I

NO-8665 Mosjøen

Norway

E-mail: nina_lorentsen@msn.com 